\title{
PENCEGAHAN DAN PENINDAKAN KENAKALAN REMAJA PADA ERA INFORMATIKA DI KABUPATEN KUNINGAN, INDONESIA
}

\author{
Erga Yuhandra \\ Fakultas Hukum, Universitas Kuningan, Kuningan, Indonesia \\ email: ergayuhandra@gmail.com
}

\begin{abstract}
Adolescence is a transitional period between children and adults, at this time there is also doubt about the role that will be done. Teenagers are no longer a child nor an adult. Teenagers begin to try to act and behave like adults, such as smoking, drinking, using drugs, and engaging in sex acts. This action is not in accordance with the norms or rules that apply in the community. The purpose of dedication to the community is more emphasized to the teenagers both men and women, as for other goals that become the purpose of this counseling is the parents who have a child to be maintained and protected for changes in social behavior in society developing with the counseling. The method used is by way of lecture and discussion then ended with question and answer. The results obtained from the devotion to this community that the community is more sensitive to legal issues, especially those associated with juvenile delinquency in the era of informatics such as today, is expected with the devotion to this society the parents, especially those with adolescents more attention and more watchful activities considered perverse.
\end{abstract}

Keywords: Prevention, Delinquency Teenagers.

\begin{abstract}
Abstrak
Remaja merupakan masa peralihan antara anak-anak dan dewasa, pada masa ini ada juga keraguan terhadap peran yang akan dilakukan. Remaja bukan lagi seorang anak dan juga bukan orang dewasa. Remaja mulai mencoba-coba bertindak dan berperilaku seperti orang dewasa, misalnya merokok, minum-minuman keras, menggunakan obat-obatan, dan terlibat dalam perbuatan seks. Tindakan ini tidak sesuai dengan norma atau aturan yang berlaku di masyarakat. Tujuan pengabdian kepada masyarakat ini lebih menitik beratkan kepada para remaja baik itu laki-laki maupun perempuan, adapun sasaran lain yang menjadi tujuan dari diadakannnya penyuluhan ini yaitu para orang tua yang mana memiliki anak yang harus dijaga dan dilindungi agar perubahan prilaku sosial yang ada di masyarakat berkembang dengan diadakannya penyuluhan. Metode yang digunakan yaitu dengan cara ceramah dan diskusi kemudian diakhiri dengan tanya jawab. Hasil yang diperoleh dari pengabdian kepada masyarakat ini yaitu masyarakat lebih peka terhadap permasalahan hukum khususnya yang berkaitan dengan kenakalan remaja di era informatika seperti jaman sekarang ini, diharapkan dengan adanya pengabdian kepada masyarakat ini para orang tua khususnya yang memiliki anak umur remaja lebih memperhatikan dan lebih mengawasi kegiatan-kegiatan yang dianggap menyimpang.
\end{abstract}

Kata Kunci: Pencegahan, Penindakan Kenakalan Remaja.

\section{PENDAHULUAN}

Dalam Tri Dharma perguruan tinggi, disebutkan bahwa salah satu tugas pendidik atau dosen adalah melakukan pengabdian kepada masyarakat. Kegiatan tersebut dilakukan untuk membantu menyelesaikan masalah-masalah sosial yang masih dimiliki bangsa khususnya bagi masyarakat pedesaan. Atas dasar itulah dilakukan pengabdian kepada masyarakat yang bertujuan ingin memberikan sumbangsih pemikiran baik itu secara teoritis maupun secara praktis yang dapat dirasakan langsung oleh masyarakat dalam bentuk pengabdian. Bantuan hukum bagi masyarakat tidak mampu diberikan dalam bentuk litigasi dan non litigasi, bantuan hukum ini bertujuan untuk 
memberikan pelayanan dalam bidang hukum. ${ }^{1}$

Dalam melaksanakan pengabdian kepada masyarakat ini, peneliti mengambil tema tentang kenakalan remaja dalam studi masalah sosial dapat dikategorikan ke dalam perilaku menyimpang. Dalam perspektif perilaku menyimpang masalah sosial terjadi karenater dapat penyimpangan perilaku dari berbagai aturan-aturan sosial ataupun dari nilai dan norma sosial yang berlaku. Perilaku menyimpang dapat dianggap sebagai sumber masalah karena dapat membahayakan tegaknya sistem sosial. Penggunaan konsep perilaku menyimpang secara tersirat mengandung makna bahwa ada jalur baku yang harus ditempuh. Perilaku yang tidak melalui jalur tersebut berarti telah menyimpang.

Remaja merupakan masa peralihan antara anak-anak dan dewasa, pada masa ini ada juga keraguan terhadap peran yang akan dilakukan. Remaja bukan lagiseorang anak dan juga bukan orang dewasa. Remaja mulai mencoba-coba bertindak dan berperilaku seperti orang dewasa, misalnya merokok, minum-minuman keras, menggunakan obat-obatan, dan terlibat dalam perbuatan seks. Tindakan ini tidak sesuai dengan norma atau aturan yang berlaku di masyarakat. Apabila tidak dikendalikan dapat menjurus kepada

\footnotetext{
${ }^{1}$ Diding Rahmat. Implementasi Kebijakan Program Bantuan Hukum Bagi Masyarakat Tidak Mampu di Kabupaten Kuningan. ISSN 2354-5976 Vol. 04 Nomor 01 Januari 2014, hlm. 35-42. Doi : $\underline{\text { https://doi.org/10.25134/unifikasi.v4i1.478 }}$
}

tindak kejahatan. Sebagai contoh remaja dari keluarga tidak mampu kecanduan obat-obatan terlarang, orang tuanya tidak bisa memberikan uang sebagai alat untuk pemuas kebutuhan sehingga tidak ada jalan lainke cuali mencuri uang temannya. Pencurian ini tergolong kejahatan yang dilakukan oleh remaja atau yang lebih dikenal sebagai kenakalan remaja (juvenile delinquency). ${ }^{2}$

Seperti yang kita ketahui sekarang ini, demikian banyak berlangsung kejadian-kejadian tindak kenakalan remaja. Bermacam-macam perbuatan negatif atau yang menyimpang dilakukan oleh beberapa remaja, yang kelihatannya dikira oleh mereka hanya biasa-biasa saja, apalagi ada yang menganggapnya sebagai sesuatu kebanggaan. Mereka sering menyebutkan perilaku tersebut hanyalah sebagai penunjukkan lambang sesuatu keberanian dirinya, namun perilaku remaja yang negatif ini, banyak masyarakat menganggap sebagai suatu perilaku yang amat memprihatinkan bagi kalangan remaja di Indonesia. ${ }^{3}$

Penyimpangan tingkah laku atau perbuatan melawan hukum yang dilakukan oleh anak, disebabkan oleh berbagai faktor, antara lain adanya dampak negatif dari perkembangan pembangunan yang cepat, arus

\footnotetext{
2 Fitri Amalia, Peran Polwiltabes Dalam Penanganan Kenakalan Remaja di Kota Semarang, Skripsi, Universitas Negeri Semarang, 2005, hlm. 1.

3 Nunung Unayah dan Muslim Sabarisman, Penomena Kenakalan Remaja dan Kriminalitas (Phenomenon of Juvenile Deliquency and Criminality), Jurnal, Puslitbang Kesejahteraan Sosial, Kementerian Sosial RI, 2015, hlm. 1.
} 
globalisasi di bidang komunikasi, kemajuan ilmu pengetahuan dan teknologi serta perubahan gaya dan cara hidup. Sebagai orang tua, telah membawa perubahan sosial yang mendasar dalam kehidupan masyarakat yang sangat berpengaruh terhadap nilai dan prilaku anak. Selain itu, anak kurang atau tidak memperoleh kasih sayang, asuhan, bimbingan dan pembinaan dalam pengembangan sikap, prilaku, penyesuaian diri, serta pengawasan dari orang tua wali, atau orang tua asuh akan mudah terseretdalam arus pergaulan masyarakat dan lingkungan yang kurang sehat dan merugikan perkembangan pribadinya. ${ }^{4}$

\section{METODE PELAKSANAAN}

Dalam melaksanakan

Pengabdian Kepada Masyarakat ini selaku pemateri saya memberikan pemaparan dalam bentuk power point agar masyarakat dapat memperhatikan dengan lebih cermat, serta menambahkan berbagai gambargambar sebagai contoh dari tema yang akan dibahas sehingga mereka lebih memahami akan realita yang sebenarnya. Adapun metode yang digunakan dalam Pengabdian Kepada Masyarakat ini melalui metode ceramah dan diskusi kemudian diakhir acara diadakan tanya jawab, dengan tanya jawab ini masyarakat diberikan kesempatan untuk bertanya sesuai dengan tema penyuluhan, atau

\footnotetext{
4 Fatoni, Proses Penyidikan Terhadap Tindak Pidana Anak di Polres Brebes Pada Tahun 2011-2012, Skripsi, UIN Sunan Kalijaga Yogyakarta, 2013, hlm. 2-3.
}

masyarakat dapat bertanya di luar tema yang telah ditentukan.

Adapun tujuan/kegunaan dari kegiatan ini sebagai wujud pelaksanaan tugas sebagai dosen melakukan kegiatan Pengabdian Kepada Masyarakat yang dampaknya dapat dirasakan langsung oleh masyarakat. Selain itu tujuan/kegunaan dari kegiatan ini adalah pertama, memberikan pemahaman kepada para orang tua terkait peran sebagai orang tua dalam melakukan pengawasan terhadap anak-anaknya. Kedua, memberikan gambaran pada masyarakat umum mengenai macam-macam kenakalan remaja di era informatika dan memberikan solusi pencegahannya.

Adapaun manfaat yang diharapkan dari pengandian kepada masyarakat ini melalui penyuluhan di bidang hukum yaitu pertama, menambah wawasan bagi masyarakat terkait masalah-masalah hukum, kedua mengetahui bermacam-macam kenakalan remaja, ketiga memberikan solusi terkait kenakalan remaja kepada masyarakat khususnya orang tua, keempat dapat mencegah tindakantindakan yang dapat menimbulkan permasalahan hukum, kelima perlu adanya kerjasama dari remaja itu sendiri, orang tua, guru dan pihakpihak lain yang terkait agar perkembangan remaja di bidang pendidikan dan bidang-bidang lainnya dapat dilalui secara terarah, sehat dan bahagia.

Sasaran kegiatan pengabdian masyarakat ini dilakukan dengan 
harapan perubahan prilaku sosial yang ada di masyarakat dengan melakukan penyuluhan dengan sasaran yang menjadi tujuan pengabdian ini lebih menitik beratkan kepada para remaja baik itu laki-laki maupun perempuan, adapun sasaran lain yang menjadi tujuan dari diadakannnya penyuluhan ini yaitu para orang tua yang mana memiliki anak yang harus dijaga dan dilindungi. Lokasi Pengabdian Kepada Masyarakat ini dilakukan tepatnya di Desa Bangunjaya Kecamatan Subang Kabupaten Kuningan yang bekerjasama dengan Tim KKN Kelompok 18 Desa Bangunjaya.

\section{HASIL DAN PEMBAHASAN}

\section{Pengertian Kenakalan Remaja}

Kenakalan remaja adalah semua perubahan anak remaja (usia belasan tahun) yang berlawanan dengan ketertiban umum (nilai dan norma yang diakui bersama) yang ditujukan pada orang, binatang, dan barangbarang yang dapat menimbulkan bahaya atau kerugian pada pihak lain Kenakalan remaja meliputi semua perilaku yang menyimpang dari norma-norma hukum pidana yang dilakukan oleh remaja. Perilaku tersebut akan merugikan dirinya sendiri dan orang-orang di sekitarnya. Juvenile Delinquency ialah perilaku jahat/ dursila, atau kejahatan/kenakalan anak anak muda ; merupakan gejala sakit (patologis) secara sosial pada anak-anak dan remaja yang disebabkan oleh satu bentuk pengabaian sosial, sehingga mereka itu mengembangkan bentuk tingkah laku menyimpang Juvenile berasal dari bahasa Latin "juvenilis", artinya anak-anak, anak muda,ciri karakteristik pada masa muda, sifatsifat khas pada periode remaja.

Delinquent berasal dari kata Latin "delinquere" yang berarti terabaikan, mengabaikan, yang kemudian diperluas artinya menjadi jahat, asosial, kriminal, aturan, pembuat ribut, pengacau, peneror, tidak dapat diperbaiki lagi, durjana, dursila, dan lain-lain. Delinquent itu selalu mempunyai konotasi serangan, pelanggaran, kejahatan, dan keganasan yang dilakukan oleh anakanak muda di bawah umur 22 tahun. ${ }^{5}$ Dari segi hukum kenakalan remaja digolongkandalam dua kelompok yang berkaitan dengan norma-norma hukum yaitu : (1) kenakalan yangbersifat amoral dan sosial serta tidak diantar dalam undang-undang sehingga tidak dapat atausulit digolongkan sebagai pelanggaran hukum ; (2) kenakalan yang bersifat melanggar

hukumdengan penyelesaian sesuai dengan undangundang dan hukum yang berlaku sama denganperbuatan melanggar hukum bila dilakukan orang dewasa. ${ }^{6}$

Kenakalan remaja menurut beberapa psikolog, secara sederhana adalah segala perbuatan yang dilakukan remaja dan melanggar aturan yang berlaku dalam masyarakat. Meskipun begitu,

Kartini Kartono, Patalogi Sosial, PT RajaGrafindo, Jakarta, 2005, hlm. 6.

Singgih D. Gunarso, Psikologi Perkembangan, PT Gramedia, 1988, hlm. 19. 
fenomena kenakalan remaja adalah sesuatu yang normal. Ketika seseorang beranjak remaja, beberapa perubahan terjadi, baik dari segi fisik maupun mental. Beberapa perubahan psikologis yang terjadi di antaranya adalah para remaja cenderung untuk resisten dengan segala peraturan yang membatasi kebebasannya. Karena perubahan itulah banyak remaja melakukan hal-hal yang dianggap nakal. Meskipun karena faktor yang sebenarnya alami, kenakalan remaja terkadang tidak bisa ditolerir lagi oleh masyarakat. Karena itu, peran orangtua sangat berpengaruh dalam membentuk kepribadian remaja ini.Berdasarkan beberapa ketentuan dalam peraturan perundangundangan memang masih tidak ditemui keseragaman mengenai usia dewasa seseorang, sebagian memberi batasan 21 (dua puluh satu) tahun, sebagian lagi 18 (delapan belas) tahun, bahkan ada yang 17 (tujuh belas) tahun. Masyarakat sebagai bagian dari penyelenggaran bantuan hukum yeng bertujuan untuk mencapai keadilan memerlukan partisipasi dari masyarakat secara luas untuk berperan dalam mendukung peyelenggaraan pemerintahan. $^{7}$

\section{Penyebab Kenakalan Remaja}

Ulah para remaja yang masih dalam tarap pencarian jati diri sering sekali

\footnotetext{
7 Suwari Akhmaddhian dan Anthon Fathanudien. Partisipasi Masyarakat dalam Mewujudkan Kuningan sebagai Kabupaten Konservasi (Studi di Kabupaten Kuningan). Jurnal $\begin{array}{lllll}\text { UNIFIKASI } & \text { Vol. } & 2 & \text { (1). }\end{array}$ DOI: https://doi.org/10.25134/unifikasi.v2i1.26
}

mengusik ketenangan orang lain. Kenakalan-kenakalan ringan yang mengganggu ketentraman lingkungan sekitar seperti sering keluar malam dan menghabiskan waktunya hanya untuk hura-hura seperti minumminuman keras, menggunakan obatobatan terlarang, berkelahi, berjudi, dan lain-lainnya itu akan merugikan dirinya sendiri, keluarga, dan orang lain yang ada disekitarnya. Cukup banyak faktor yang melatar belakangi terjadinya kenakalan remaja. Berbagai faktor yang ada tersebut dapat dikelompokkan menjadi faktor internal dan faktor eksternal.

\section{a. Faktor Internal}

1) Faktor Kepribadian yaitu kepribadian adalah suatu organisasi yang dinamis pada system psikosomatisdalam individu yang turut menentukan caranya yang unik dalam menyesuaikan dirinya dengan lingkungannya (biasanya disebut karakter psikisnya). Masa remaja dikatakan sebagai suatu masa yang berbahaya. Pada periode ini, seseorang meninggalkan masa anak-anak untuk menuju masa dewasa. Masa ini di rasakan sebagai suatu Krisis identitas karena belum adanya pegangan, sementara kepribadian mental untuk menghindari timbulnya kenakalan remaja atau perilaku menyimpang.

2) Faktor Kondisi Fisik yaitu faktor ini dapat mencakup segi cacat atau tidaknya secara fisik dan segi jenis kelamin. Ada suatu teori yang 
menjelaskan adanya kaitan antara cacat tubuh dengan tindakan menyimpang (meskipun teori ini belum teruji secara baik dalam kenyataan hidup). Menurut teori ini, seseorang yang sedang mengalami cacat fisik cenderung mempunyai rasa kecewa terhadap kondisi hidupnya. Kekecewaan tersebut apabila tidak disertai dengan pemberian bimbingan akan menyebabkan si penderita cenderung berbuat melanggar tatanan hidup bersama sebagai perwujudan kekecewaan akan kondisi tubuhnya.

3) Faktor Status dan Peranannya di Masyarakat yaitu Seseorang anak ${ }^{8}$ yang pernah berbuat menyimpang terhadap hukum yang berlaku, setelah selesai menjalankan proses sanksi hukum (keluar dari penjara), sering kali pada saat kembali ke masyarakat status atau sebutan "eks narapidana" yang diberikan oleh masyarakat sulit terhapuskan sehingga anak tersebut kembali melakukan tindakan penyimpangan hukum karena meresa tertolak dan terasingkan.

Pasal 28B Ayat (2) UUD NRI Tahun 1945 mengatakan bahwa setiap anak berhak atas kelangsungan hidup, tumbuh, dan berkembang serta berhak atas perlindungan dari kekerasan dan diskriminasi. Hal tersebut berkaitan dengan Konvensi PBB tentang Hak Anak, berdasarkan Pasal 74 Undang-Undang Nomor 23 Tahun 2002 tentang Perlindungan Anak (LNRI Tahun 2002 Nomor 109, TLN Nomor 4235), telah pula dibentuk Komisi Perlindungan Anak Indonesia (KPAI) dengan Keputusan Presiden Nomor 77 Tahun 2003. Lihat Jimly Asshiddiqie, Komentar Atas UndangUndang Dasar Negara Republik Indonesia Tahun 1945, Sinar Grafika, Jakarta, 2009, hlm. 115.

\section{b. Faktor Eksternal}

1) Kondisi Lingkungan Keluarga yaitu khususnya di kota-kota besar di Indonesia, generasi muda yang orang tuanya disibukan dengan kegiatan bisnis sering mengalami kekosongan batin karena bimbingan dan kasih sayang langsung dari orang tuanya sangat kurang. Kondisi orang tua yang lebih mementingkan karier daripada perhatian kepada anaknya akan menyebabkan munculnya perilaku menyimpang terhadap anaknya. Kasus kenakalan remaja yang muncul pada keluarga kaya bukan karena kurangnya kebutuhan materi melainkan karena kurangnya perhatian dan kasih sayang orang tua kepada anaknya.

2) Kontak Sosial dari Lembaga Masyarakat Kurang Baik atau Kurang Efektif apabila sistem pengawasan lembaga-lembaga sosial masyarakat terhadap pola perilaku anak muda sekarang kurang berjalan dengan baik, akan memunculkan tindakan penyimpangan terhadap nilai dan norma yang berlaku. Misalnya, mudah menoleransi tindakan anak muda yang menyimpang dari hukum atau norma yang berlaku, seperti mabuk-mabukan yang dianggap hal yang wajar, tindakan perkelahian antara anak muda dianggap hal yang biasa saja. Sikap kurang tegas dalam menangani tindakan penyimpangan perilaku ini akan semankin meningkatkan kuantitas dan kualitas tindak 
penyimpangan di kalangan anak muda.

3) Kondisi Geografis atau Kondisi Fisik Alam yaitu Kondisi alam yang gersang, kering, dan tandus, dapat juga menyebabkan terjadinya tindakan yang menyimpang dari aturan norma yang berlaku, lebihlebih apabila individunya bermental negative. Misalnya, melakukan tindakan pencurian dan mengganggu ketertiban umum, atau konflik yang bermotif memperebutkan kepentingan ekonomi.

4) Faktor Kesenjangan Ekonomi dan Disintegrasi Politik yaitu kesenjangan ekonomi antara orang kaya dan orang miskin akan mudah memunculkan kecemburuan sosial dan bentuk kecemburuan sosial ini bisa mewujudkan tindakan perusakan, pencurian, dan perampokan. Disintegrasi politik (antara lain terjadinya konflik antar partai politik atau terjadinya peperangan antar kelompok dan perang saudara) dapat mempengaruhi jiwa remaja yang kemudian bisa menimbulkan tindakan-tindakan menyimpang.

5) Faktor Perubahan Sosial Budaya yang Begitu Cepat (Revolusi) yaitu Perkembangan teknologi di berbagai bidang khususnya dalam teknologi komunikasi dan hiburan yang mempercepat arus budaya asing yang masuk akan banyak mempengaruhi pola tingkah laku anak menjadi kurang baik, lebihlebih anak tersebut belum siap mental dan akhlaknya, atau wawasan agamanya masih rendah sehingga mudah berbuat hal-hal yang menyimpang dari tatanan nilai-nilai dan norma yang berlaku

\section{Perilaku-perilaku yang merupakan kenakalan remaja}

Berdasarkan pengertian

kenakalan remaja diatas kami mengadakan pengamatan tentang beberapa perilaku remaja yang termasuk kenalan remaja di lingkungan sekitar, berikut beberapa contoh kenakalan remaja yang ada di lingkungan sekitar kami :

a. Perbuatan awal pencurian meliputi perbuatan berkata bohong dan tidak jujur;

b. Perkelahian antar siswa termasuk juga tawuran antar pelajar;

c. Memusuhi orang tua dan saudara, meliputi perbuatan berkata kasar dan tidak hormat pada orang tua dan saudara;

d. Merokok dan Mabuk-mabukan;

e. Menonton video atau media cetak yang tidak layak;

f. Membolos dan mengendarai kendaraan di bawah umur tanpa helm;

g. Selalu melanggar tata tertib.

\section{SIMPULAN}

Hasil yang diperoleh dari pengabdian kepada masyarakat ini yaitu masyarakat lebih peka terhadap permasalahan hukum khususnya yang berkaitan dengan kenakalan remaja di era informatika seperti jaman sekarang 
ini, diharapkan dengan adanya pengabdian kepada masyarakat ini para orang tua khususnya yang memiliki anak umur remaja lebih memperhatikan dan lebih mengawasi kegiatan-kegiatan yang dianggap menyimpang. Dengan kegiatan ini pemahaman tentang hukum masyarakat menjadi meningkat dan sangat antusias dengan kegiatan pengabdian tersebut. Tentang kegiatan ini saya merekomendasikan agar kegiatan pengabdian kepada masyarakat perlu ada upaya antara LPPM Uniku berkerja sama dengan pemerintahan desa supaya kegiatan pengabdian ini optimal dan dapat dilakukan secara berjangka, sehingga peran serta masyarakat lebih antusias.

\section{DAFTAR PUSTAKA}

Diding Rahmat. Implementasi Kebijakan Program Bantuan Hukum Bagi Masyarakat Tidak Mampu di Kabupaten Kuningan. ISSN 23545976 Vol. 04 Nomor 01 Januari 2014, hlm. 35-42. Doi : https://doi.org/10.25134/unifikas i.v4i1.478

Fatoni, Proses Penyidikan Terhadap Tindak Pidana Anak di Polres Brebes Pada Tahun 2011-2012, Skripsi, UIN Sunan Kalijaga Yogyakarta, 2013.

Fitri Amalia, Peran Polwiltabes Dalam Penanganan Kenakalan Remaja di Kota Semarang, Skripsi, Universitas Negeri Semarang, 2005.

Jimly Asshiddiqie, Komentar Atas Undang-Undang Dasar Negara
Republik Indonesia Tahun 1945,

Sinar Grafika, Jakarta, 2009.

Kartini Kartono, Patalogi Sosial, PT RajaGrafindo, Jakarta, 2005.

Nunung Unayah dan Muslim

Sabarisman, Penomena Kenakalan Remaja dan Kriminalitas (Phenomenon of Juvenile Deliquency and Criminality), Jurnal, Puslitbang Kesejahteraan Sosial, Kementerian Sosial RI, 2015.

Singgih D. Gunarso, Psikologi Perkembangan, PT Gramedia, 1988.

Suwari Akhmaddhian dan Anthon Fathanudien. Partisipasi Masyarakat dalam Mewujudkan Kuningan sebagai Kabupaten Konservasi (Studi di Kabupaten Kuningan). Jurnal UNIFIKASI Vol. $2 \quad$ (1). 2015 . DOI: https://doi.org/10.25134/unif ikasi.v2i1.26

\section{Peraturan Perundang-undangan}

Undang-Undang Dasar Negara Republik Indonesia Tahun 1945. Undang-Undang Republik Indonesia Nomor 1 Tahun 1974 tentang Perkawinan.

Undang-Undang Republik Indonesia Nomor 11 Tahun 2008 tentang Informasi dan Transaksi Elektronik.

Undang-Undang Republik Indonesia Nomor 11 Tahun 2012 tentang Sistem Peradilan Pidana Anak.

Undang-Undang Republik Indonesia Nomor 11 Tahun 2016 tentang Bantuan Hukum. 